\title{
Ecological Damage at Pollution by Oil Products on the Example of R. Shava, Nizhny Novgorod Region
}

Nabeeva E.G.

Mingazova N.M.

Mingaliyev R.R.

Kazan Federal University, Institute of Management, Economics and Finance, Kazan, 420008, Russia

Doi:10.5901/mjss.2014.v5n24p426

\begin{abstract}
Article is devoted to the analysis of the ecological damage caused to water object - the river Shava and to wetland Shava of the Nizhny Novgorod Region, injured with accident at oil spill in 2007. Environment components, the most sensitive to oil pollution are analyzed and allocated. The economic assessment of consequences of pollution is carried out.
\end{abstract}

Keywords: oil pollution, ecological damage, small rivers, fauna, flora, soils, water.

\section{Introduction}

As a result of the accident from the Almetyevsk-Nizhny Novgorod oil pipeline which took place in March, 2007 in the Kstovsky region of the Nizhny Novgorod Region there was a pollution of water ecosystems of the river Shava and wetland of river Shava diesel fuel. Thus the food supply of fish resources (a phytoplankton, a zooplankton, a zoobenthos) and fish resources of the river Shava suffered, ground deposits and coastal soil are polluted, and the part of water vegetation and fauna was lost. The purpose of the conducted research is the complex assessment of the ecological damage caused to water object (to river Shava and wetland of river Shava) at an emergency (Mingazova, 2014).

For an assessment of full ecological damage natural researches with sampling and studying of structural indicators of components of an ecosystem of water objects were conducted. Further the analysis of the existing emergency was carried out; the assessment of impact of an emergency on various components of the environment was carried out. The received information allowed to make an economic assessment of consequences of pollution of water objects oil products.

The assessment of impact of an emergency on food supply of fish resources and fish resources of the river Shava is carried out; calculation of the damage caused to fish stocks of river Shava by emergency oil spill; calculation of damage to water object for hydrochemical indicators; calculation of damage to fauna; calculations of the damage caused to a soil cover of wetland of river Shava; an assessment of the damage caused to vegetation.

\section{Methods}

In calculations of damage from emergency oil spills were used, generally modern techniques of the Ministry of Natural Resources and Environmental Protection of the Russian Federation. Branch and regional techniques weren't used in order to avoid disputed issues at coordination of the extent of ecological damage. The used techniques are well applicable to situations with emergency oil spills. For carrying out calculations were used: for an assessment of damage to soils "A technique of calculation of the extent of the harm done to soils as to object of the environmental protection" approved by the Ministry of Natural Resources and Environmental Protection of the Russian Federation, the order of July 8, $2010 \mathrm{~N} 238$., it is intended for cases of emergence of emergency and emergency situations of natural and technogenic character (for example, emergency oil spill). For a damage assessment from pollution of water object "The technique of calculation of the extent of the harm done to water objects owing to violation of the water legislation" was used. Damages to fauna were assessed by "A technique of calculation of the extent of the harm done to the objects of fauna included in the Red List of the Russian Federation, and also to other objects of fauna which aren't relating to objects of hunting and fishery and the environment of their dwelling". Calculation of damage to fish resources of the river Shava was carried out 
by "A technique of calculation of the damage caused to fishery as a result of dumping in fishery reservoirs of sewage and other waste" (it is approved by Ministry of Fisheries of the USSR on August 26, 1967 No. 30-1-11 (the Technique ... 1967).

\section{Results}

The river Shava flows in the Kstovsky district of the Nizhny Novgorod Region (fig. 1). The river Shava is inflow of the second order of the Volga River - inflow of the river of Kudma - right-bank inflow of the Volga River, belongs to the rivers low-studied in the hydrological relation.

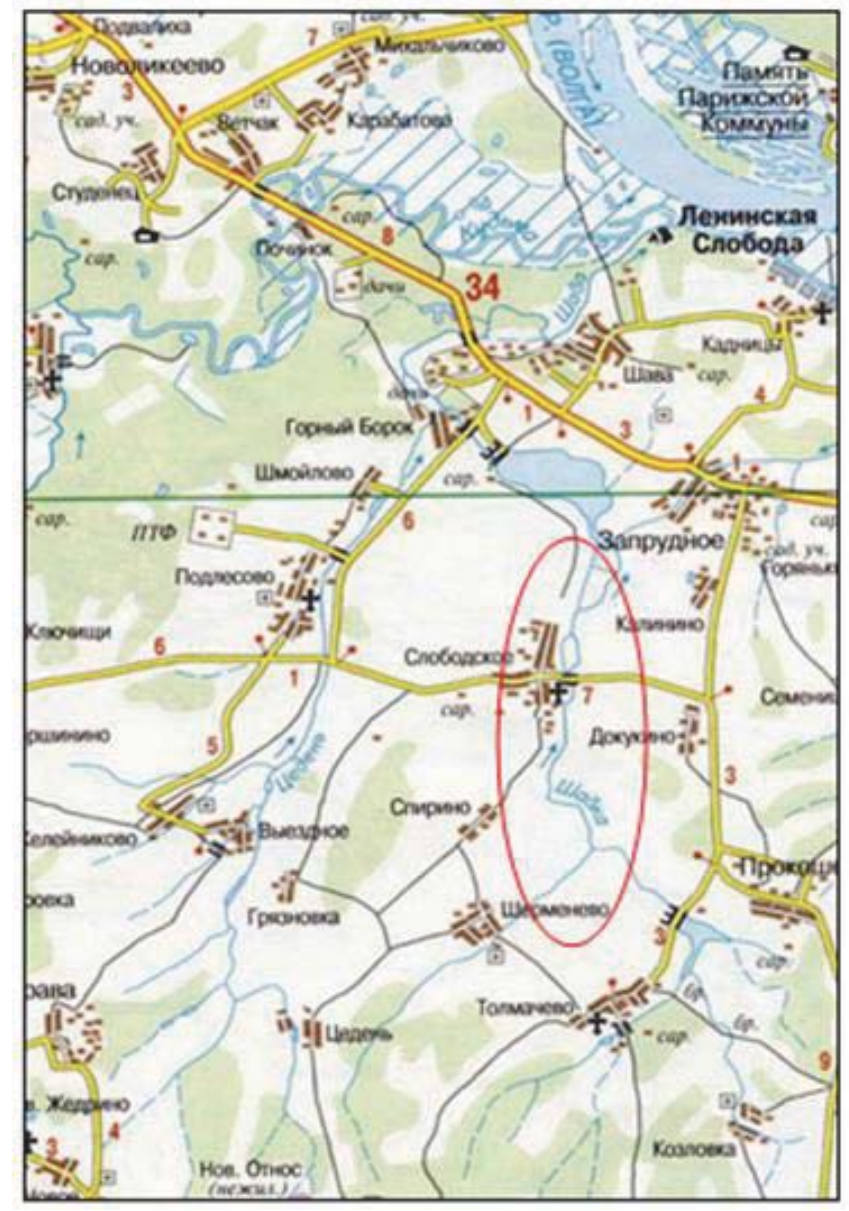

Fig. 1. The river Shava on the map of the Nizhny Novgorod Region.

In 18 km from a source of river Shava forms extensive wetland ("the Bog Shava" - a conservation monument).

After passing through wetland the river Shava forms, the handmade Borkovsky pond. After the Borkovsky pond the waters dumped from a dam come via the artificial channel to the bed of the river Shava.

At emergency flood from a slope surface oil products (diesel fuel) got to the river Shava. Diesel fuel got also to the finishing pond of "Borok" formed by a dam on the river Shava, and further in the river to Kudma. Accident pollution of the river Shava resulted, from a nature sanctuary of regional value "the Bog "Shava", fish-breeding ponds of Fish Farm "Borok" and lands of agricultural purpose of "Zaprudnovskoye" farm.

The most part of oil products is accumulated by peat soils of wetland of river Shava around accident. The total amount of the spread oil product made $309,05 \mathrm{~m}^{3}$. Borders of distribution of an ecologic disaster area are rather great and it is connected, first of all, by hit of diesel fuel to the river Shava, and then possible hit in the Volga River.

In this work damages to biological resources (to hydrobionts, fauna, vegetation), to soils, water objects are assessed. 


\section{Damage to Biological Objects}

Falling in a reservoir, oil products made adverse effect on food supply of fishes, i.e. on phyto - and a zooplankton, a benthos and the highest water vegetation.

For an assessment of damage research of a condition of biological communities (a phytoplankton, a zooplankton, a zoobenthos) by the standard hydrobiological methods, estimates of quality of waters on physical and chemical and hydrobiological indicators was conducted. Points of control included sites above a pollution place, around accident, in a place of a confluence of river Shava in a pond, below a pond at the exit of river Shava.

When studying a phytoplankton quality of water by the Zhukinsky's classification (An ecological assessment ..., 1990) during the spring period changed from the class "pure" of the categories "the very pure-quite pure" at stations above and below flood to the class "dirty" of the category "the very dirty" on a place of intake of oil products. Improvement of quality of water in process of removal of station of selection from an oil spill place was noted.

The community of a zooplankton in the river Shava differed in a low specific variety, low sizes of quantitative indices, the broken structure of communities throughout the river.

On indicators of a zoobenthos it is possible to draw a conclusion on decline in quality of water owing to emergency dumping of oil products, communities of organisms in the place of accident underwent the greatest influence; on an entrance to a pond and above a flood place the community of a zoobenthos is in a steady safe state.

When studying a fish fauna it is revealed that impact on a fish fauna was made the period of a freezing and later. As a result of the made impact of oil products fish was dormant, in a consequence it was dead on river length about 10 $\mathrm{km}$ (to the Borkovsky pond and after it). Directly on a site of research about $2 \mathrm{~km}$ long the lost fishes of such types as a silver carp, small fry, a perch and the bream were found. Total lost individuals, by results of natural researches on the studied site were about 500 pieces.

When comparing impact on hydrobiological components of an ecosystem it is revealed that the zoobenthos and a fish fauna underwent the greatest influence.

The average on all biological components influence is estimated at 4,25 points and interpreted as "strong". Influence affected also on other biotic components (a gerpetofauna, an intomofauna, etc.).

As for a benthos, it is the most vulnerable component of water ecosystems owing to smaller mobility of organisms, the big period of restoration. Oil products collapsed eventually, the heaviest fraction settled on a bottom therefore there was a full death of benthos, mostly motionless and inactive (epifauna) and forms which are burying (infauna) and also considerable death of mobile forms (onfauna) on a site about $125 \mathrm{sq} . \mathrm{m}$, the general biomass of $1787,5 \mathrm{mg}$.

Further the damage caused to stocks of fishes by violation of natural reproduction as a result of death of producers is defined. As for small fry, in view of shallowness of river Shava $(0,2-1,0 \mathrm{~m})$ this look spawns or in its lower reaches and that is more probable - in the river of Kudma which inflow is the river Shava. The general damage at the cost of the lost fish makes 2340 rubles for a site of the river of $2 \mathrm{~km}$ (below the Borkovsky pond). Taking into account that the death of fish was noted during the different periods on a site of the river about $10 \mathrm{~km}$ long, it is possible to accept that the damage to fishery made $(2,340$ t.r. $x 10 / 2)$ about 11,7 thousand rubles.

The total amount of damage to fishery calculated on the volume of capital investments (To) of actions for preservation and reproduction of fish stocks, necessary for implementation, at a stage of the scheme and in projects on building of fish-breeding objects makes 20,1 t.rub. (for the followed site of the river Shava about $2 \mathrm{~km}$ long). Taking into account that the death of fish was noted during the different periods on a site of the river about $10 \mathrm{~km}$ long, it is possible to accept that the damage to fishery will make (20,1 t.rub. x 10/2) about 100,5 t. rub (hundred thousand five hundred rubles). This sum is offered to be taken as total on an amount of damage to fishery of the river of Shava. The damage is given for 2007, without inflation during 2007-2011.

\section{Damage to Fauna}

By results of the researches conducted in 2007 and 2011years are revealed that the territory of a nature sanctuary - "The Bog Shava" differed in a considerable specific variety before pollution as a result of emergency flood of 2007.

Wetland "Shava", according to department of protection of fauna of the Ministry of Agriculture of the Nizhny Novgorod Region, was a habitat valuable to the animals living near the water (a beaver, a muskrat, a mink American, a steppe polecat, an ermine, a raccoon dog) and songbirds. In the gerpetofauna of a bog Shava 3 species is revealed (a lake frog, a grass frog, ordinary grass-snake). In avifauna were noted: the big black-tailed godwit, a snipe, double snipe, a lapwing, the herbalist, ruff, a great number of ducks (a wild duck, etc.), seagulls, sea-swallow, ducks, herons, in 2007 was marked out a white stork, a great number of songbirds ("The report of employees of the reserve Kerzhensky"). In 
avifauna in the spring of 2007 the rare protected species - the white blue tit included in the Red List of the Nizhny Novgorod Region and the Red List of Russian Federation was revealed at the place of accident.

Emergency flood in 2007 was resulted by pollution of wetland Shava, thus: habitats of animals are destroyed; individuals of directly lost animals are marked out.

As a result of the happened accident harm to objects of fauna is done: employees of the reserve "Kerzhensky" in 2007 noted destruction of 929 exemplars of amphibians, 1 ex. of reptiles, 174 ex. of birds, 6 ex.of mammals.

Settlement data on the area which underwent pollution and data of the reserve "Kerzhensky" on quantity of the lost individuals formed the basis of calculations of the damage caused to fauna. The extent of the damage caused by destruction of habitat, caused to objects of fauna, not belonging to invertebrate animal species made 605900 rub (six hundred five thousand nine hundred rubles).

The extent of the harm done by destruction of the soil and other habitats of invertebrate animals makes 87,298 million rubles (eighty seven million two hundred ninety eight thousand rub). The losses which are giving in to calculation from death of objects of fauna made 70000 rub (seventy thousand rubles). The general extent of damage to fauna makes 87, 974 million rub (eighty seven million nine hundred seventy four thousand rubles) in the prices for 2007 (without inflation during the period from 2007 to 2011).

The most strongly negative impact affected such groups of organisms as soil invertebrates, reptiles, near water birds and mammals.

\section{Damage of Vegetation}

On the basis of studying of specific structure of wood and shrubby vegetation at the river Shava it is revealed that this vegetation is typical for inundated habitats. Rare especially protected species of trees and bushes were not revealed. The condition of wood and shrubby vegetation of wetland Shava is characterized as weakened that is connected with a number of factors (hydrological conditions of bogs, abnormally droughty summer of 2010, anthropogenic factors - a cattle pasture, a mow cleaning). Therefore it is correct to track impact on wood and shrubby vegetation of consequences of accident of 2007 it isn't possible, the caused damage currently can't be accurately defined in a cost form.

\section{Damage to Water Object}

The extent of the damage caused to water object by emergency pollution by oil products paid off by three methods:

1) calculation with the admission that all volume of the spread oil products (namely $309,05 \mathrm{~m} 3$ ) got to water of river Shava, the river Shava by emergency pollution by oil products made the extent of the damage caused: 519,280088 million rubles;

2) calculation for the available data on concentration of the dissolved and emulsified oil products in water of river Shava from March 12 to March 15, made the extent of the damage caused to river Shava by emergency pollution by oil products in 8,527328 million rubles;

3) calculation, according to the provision of the Technique about calculation of the damage caused to water object by emergency pollution by oil products in the absence of reliable data about the volume of the polluting substances which got to water, the extent of the damage caused to river Shava by emergency pollution by oil products, made 3,72 million rubles.

Taking into account the fact that at accident the considerable part of oil products was accumulated by peat soils of wetland of river Shava around accident, and also from the point of view of methodical validity calculation for 5 concentration of the polluting substances in March, 2005 is represented the most acceptable. Respectively, the most acceptable extent of the damage caused to a site of the river Shava from the place of accident to an entrance to a finishing pond at emergency pollution by oil products of a site the sum of 8,5273275 million rubles is represented.

Taking into account the last remark, the total amount of the damage caused to river Shava at emergency pollution by oil products (damage to water object + damage to fish stocks) makes 8,527328 million rubles $+0,101$ million rubles $=$ 8,628328 million rubles.

\section{Soil Damage}

According to the obtained data for 2011, the studied soils of wetland Shava belong to type of alluvial inundated soils. Soils of this type are characterized by high biological activity and high potential fertility. Pollution is noted on a place of emergency flood (at crossing of the river Shava on a bog Shava). Here pollution was noted after carrying out recovery 
actions in 2009, remained in the form of residual quantities also in 2011. Oil products on this site were observed up to the depth of $1 \mathrm{~m}$. On other sites of wetland Shava oil products were noted in insignificant quantities at depths within $0-50 \mathrm{~cm}$.

The content of oil products in the soil during the period from May to June, 2011 changed at stations from 106,5 $\mathrm{mg} / \mathrm{kg}$ at background station to $220-4693 \mathrm{mg} / \mathrm{kg}$ on a place of emergency flood. In a certain degree the place of emergency flood is more polluted. The decision of arbitration court of the Nizhny Novgorod Region of 20.01.2010 approved criteria of completion of recovery (remediation) work - achievement of the content of oil products: in soils of a coastal strip of river. These criteria (DOSNP) is lower on a watercourse from the place of accident to a confluence with a finishing pond of fish farm of "Borok" at a depth from 0 to $30 \mathrm{~cm}$ - to $850 \mathrm{mg} / \mathrm{kg}$.

By results of researches of 2011 it is possible to draw a conclusion on considerable decrease (in comparison with 2007) contents of oil products in a soil layer (on average to $100-150 \mathrm{mg} / \mathrm{kg}$ in a blanket that corresponds the accepted DOSNP criteria of restoration which is $850 \mathrm{mg} / \mathrm{kg}$ ). More polluted is a site 2, in an oil spill place.

For calculation of the damage caused to soils in 2007 as a result of accident the area of pollution taking into account a rating by a current and a hydrological situation of 2007-2011 was determined. It is calculated, that Shava in 2007 with the area of a bog and the river of 50,8084 hectares underwent pollution of the soil of wetland (that is more than 50 hectares) while Shava makes the area of all bog to 400 hectares). Thus, not all territory of wetland of river Shava was subjected to pollution, but only soils about $1 / 8$ parts of all bog - protected area "Bog Shava".

The damage paid off according to the maximum content of oil products in the soil in 2009, in the absence of fuller data suitable for calculations, on all territory for 2007. Calculation was carried out on two sites (the place of accident 1,947 hectares and the polluted wetland site at high water level $-48,857$ hectares). The damage on soils at the place of accident made 116,82 million rubles, to soils in the territory of wetland - 762169200 rub.

Oil products on the river Shava and bogs Shava makes the general total damage from pollution as a result of accident of 2007 of soils according to settlement data makes 878, 989 million rubles. Considering that calculation was carried out according to 2009 (during decrease in concentration as a result of application of recovery actions by the owner of the oil pipeline), the damage for 2009 could be more. Therefore, the damage, available to calculation, from pollution of soils makes not less than 878 million 989 thousand 200 rub.

\section{Conclusions}

At calculation of ecological damage to the river Shava and to a bog Shava the following results are revealed.

Oil products on the river Shava and a bog (wetland) Shava makes the general total damage from pollution as a result of accident of 2007 of soils on settlement these 878,9892 million rubles.

Total amount of damage to water object at pollution by oil products and damage to fish stocks makes 8,628328 million rubles.

The general extent of damage to fauna makes 87,974 million rubles in the prices for 2007.

The damage to fishery makes about 100,5 t. rub (hundred thousand five hundred rubles). It isn't possible to calculate damage to flora in view of lack of reliable data about death of plants.

Having compared the received results it is possible to draw a conclusion on the greatest economic damage to soils. Soils appeared the most vulnerable component at emergency oil spill. Also extensive damage is caused to fauna that is explained by accommodation this territory of valuable bird species and mammals.

\section{References}

N. M. Mingazova. Criteria of rehabilitation of biotic communities in oil-polluted small rivers (by example of the Shava River, Nizhnii Novgorod oblast). N. M. Mingazova, O. Yu. Derevenskaya, O. V. Palagushkina, E. G. Nabeeva, L. V. Blatt. // Inland Water Biology, July 2014, Volume 7, Issue 3, pp 192-200.

The passport on the state nature sanctuary of regional (regional) value "Bog Shava" / by the decision of Gorky regional executive committee No. 545 of 20.08.1975 - Nizhny Novgorod, 2003.

The report on the contract No. 35 of May 10, 2007. "Determination of the extent of damage from destruction of objects of a plant and animal life and violation of the environment of their dwelling in the territory of the state nature sanctuary "the Bog Shava" I Zapovednik Kerzhensky Federal State Institution. - N. Novgorod, 2007. - 50 pages.

The guide to methods of an assessment of ecological damage (on bioresources). - Kazan: Kazan university, 2011. - 115 pages.

An ecological assessment of impact of hydrotechnical construction on water objects. Kiev: Naukova thought, 1990.-256 pages.

The federal law on modification of the Federal law "About fishery and preservation of water biological resources and separate acts of the Russian Federation" of 28.12.2010 No 420 - Federal Law.

A temporary technique of an assessment of the damage caused to fish stocks as a result of construction, reconstruction and expansion 
of the enterprises, constructions and other objects and carrying out different types of works on fishery reservoirs. It is approved Goskompriroda SSSR 20.10.1989, Minrybkhoz SSSR 18.12.89, the Ministry of Finance of the USSR 21.12.1989.

A technique of determination of the extent of damage from degradation of soils and lands (By the Ministry of Natural Resources and Environmental Protection of the Russian Federation of 11.07.1994 and Goskomzemom of Russia in 1994, it is coordinated Minselkhozprodukt of Russia 1994).

The technique of calculation of the extent of the harm done to the objects of fauna included in the Red List of the Russian Federation, and also to other objects of fauna which aren't relating to objects of hunting and fishery and the environment of their dwelling approved Ministestvom of natural resources of the Russian Federation 28.04.2008.

A temporary standard technique of determination of economic efficiency of implementation of nature protection actions and an assessment of the economic damage caused to a national economy by environmental pollution. M, 1986.

A technique of definition of damage to surrounding environment at accidents on the main oil pipelines", утв. Ministry of Fuel and Energy of the Russian Federation 01.11.1995.

A technique of calculation of the damage caused to fishery as a result of dumping in fishery reservoirs of sewage and other waste (by Minrybkhoz SSSR 16.08.67 No. 30-1-11). 